\title{
DOE/RW- 98005818
}

\section{Integration of MGDS Design into the Licensing Process ${ }^{1}$}

\section{Introduction}

This paper presents an overview of how the Mined Geologic Disposal System (MGDS) design for a potential repository is integrated into the licensing process. The integration process employs a two-fold approach: (1) ensure that the MGDS design complies with applicable Nuclear Regulatory Commission (NRC) licensing requirements, and (2) ensure that the MGDS design is appropriately reflected in a license application that is acceptable to the NRC for performing acceptance and compliance reviews.

\section{Work Description: Designing for Regulatory Compliance}

The licensing process relies on a structured series of pre-licensing interactions between the NRC and Office of Civilian Waste Management (OCRWM) that focus on resolving licensing issues before the preparation and docketing of the license application. The license application will contain considerable detail regarding the design of the repository, and in particular, will require a demonstration that all applicable NRC licensing requirements are met. NRC licensing requirements consist of rules that govern application for a license to receive and possess highlevel radioactive waste at a geologic repository and technical criteria that address performance objectives and design criteria, which the MGDS design must satisfy in order to support a finding

${ }^{1}$ This work was supported by the Yucca Mountain Site Characterization Office as part of the Civilian Radioactive Waste Management Program. This project is managed by the U.S. Department of Energy, Yucca Mountain Site Characterization Project. 


\section{DISCLAIMER}

This report was prepared as an account of work sponsored by an agency of the United States Government. Neither the United States Government nor any agency thereof, nor any of their employees, makes any warranty, express or implied, or assumes any legal liability or responsibility for the accuracy, completeness, or usefulness of any information, apparatus, product, or process disclosed, or represents that its use would not infringe privately owned rights. Reference herein to any specific commercial product, process, or service by trade name, trademark, manufacturer, or otherwise does not necessarily constitute or imply its endorsement, recommendation, or favoring by the United States Government or any agency thereof. The views and opinions of authors expressed herein do not necessarily state or reflect those of the United States Government or any agency thereof. 
of no unreasonable risk.

To ensure that the license application appropriately addresses NRC licensing requirements, a Technical Guidance Document for Preparation of the License Application (TGD) is being written to provide draft acceptance criteria for the project staff to use in preparing the license application. These draft acceptance criteria will include NRC regulatory guides, industry codes and standards, Staff Technical Positions, and Staff Positions. The development of acceptance criteria is being achieved through inputs from the Engineering Compliance Program (ECP), which is a formal program to assess regulatory guidance and industry experience documents and codes and standards to determine their applicability to MGDS design. These determinations, along with supporting rationale, are documented in ECP Guidance Packages. ECP Guidance Packages are used as input to the System Description Documents upon which the MGDS design will be based. ECP Guidance Packages are comprised of guidance sheets, each written to defined elements of the repository system, that capture appropriate regulatory precedent that will ensure that the MGDS design complies with NRC licensing requirements, and will thereby facilitate the NRC's timely and successful review of the license application. ECP Guidance Packages also provide input to Engineering Design Guides and analyses related to Design Bases Events. Thus, the ECP directly influences design activities and the TGD guides engineering inputs into the license application.

The TGD focuses on the license application itself and will prescribe the acceptance criteria for determination of compliance against applicable licensing requirements for each part of the license application. Regulatory precedence applicable to MGDS design and documented in ECP 
Guidance Packages is allocated to the appropriate design chapters in the license application. This information is integrated with NRC guidance from the Format and Content for the License Application for the High-Level Waste Repository (NRC, 1990) and the License Application Review Plan for a Geologic Repository for Spent Nuclear Fuel and High-Level Radioactive Waste (LARP) (NRC, 1995). The resulting integration forms the basis to generate the detailed guidance, primarily as acceptance criteria, to the various engineering and technical disciplines regarding input requirements for the license application. This process also serves as a technical check by ensuring that each part of the license application will contain the type of information requested by the NRC, that it will be provided in the level of detail specified by the NRC, and that the information will be provided in the proper form and format to facilitate review by the NRC staff. The ECP Guidance Packages form the basis to construct detailed licensing guidance for developing the license application, contained in the TGD as acceptance criteria, which should mirror the acceptance criteria included in NRC's LARP.

In addition to following the guidance contained the LARP, the TGD will also capture the license application format in NRC Standard Review Plans for facilities such as nuclear power plants (NRC, 1987), low-level waste disposal (NRC, 1994), dry cask storage systems (NRC, 1996a), and spent fuel dry storage facilities (NRC, 1996b). Each chapter of the TGD will parallel each chapter of the license application, including the corresponding subsections. Each TGD chapter will contain both general guidance applicable to all subsections of the chapter and specific guidance for each of the chapter subsections. Each TGD chapter will specify the acceptance criteria against which compliance is to be reviewed and where they are to addressed, the applicability of regulatory guides and industry codes and standards, and the approach to be taken 
in organizing the information within the license application itself.

Although directed toward the writers of the license application, the TGD impacts scheduling of activities to comport with differing levels of design detail needed for the application. In particular, safety systems are prioritized based on the need for greater design maturity, longer pre-licensing reviews, and greater in-depth compliance demonstrations.

\section{Conclusion}

Use of licensing-focused planning and guidance tools will result in a license application that contains design information with the proper topic-specific level of detail and supporting analyses. 


\section{References}

NRC 1987. Standard Review Plan for the Review of Safety Analysis Reports for Nuclear Power Plants, NUREG-0800. Washington, D.C.: U.S. Government Printing Office.

NRC 1990. Format and Content for the License Application for the High-Level Waste Repository.

DG-3003. Washington, D.C.: U.S. Government Printing Office

NRC 1994. Standard Review Plan for the review of a license application for a Low-Level Radioactive

Waste Disposal Facility, NUREG-1200, Rev. 3. Washington, D.C.: U.S. Government Printing Office.

NRC 1995. License Application Review Plan for a Geologic Repository for Spent Nuclear Fuel and High-Level Radioactive Waste. NUREG-1323. Rev. 01. Washington, D.C.: U.S. Government Printing Office.

NRC 1996a. Standard Review Plan for Dry Cask Storage Systems, NUREG-1536. Washington, D.C.: U.S. Government Printing Office.

NRC 1996b. Standard Review Plan for Spent Fuel Dry Storage Facilities, Draft NUREG-1567.

Washington, D.C.: U.S. Government Printing Office. 
Report Number (14) DOE/RW- -98005818

Publ. Date (11)

Sponsor Code (18)

UC Category (19)

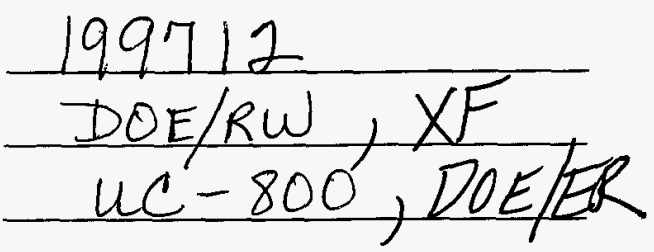

no 1332.15 included in folder

\section{0}

DTIC QUALTTY DVOPECTED I 